\title{
Characterisation of Bambara Groundnut Based On Morphometric Diversity
}

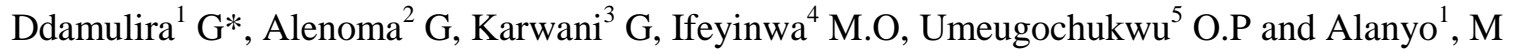

\begin{abstract}
Sixty nine Vigna subterranean accessions were evaluated at Namulonge to determine their genetic variability in a randomized complete block design with three replications. Analysis of variance showed significant $(\mathrm{P}<0.01)$ divergence among accessions for all traits. Cluster analysis exhibited six distinct clusters with the highest intra-cluster distance (8.09) observed in cluster II and the lowest distance (0.00) in cluster VI. Maximum inter-cluster distance was observed between cluster VI and IV and minimum distance between cluster II and IV. Inter-cluster distance was much higher than intra-cluster distance suggesting a wider variability among accessions. All late maturing accessions with high yield were grouped in cluster $\mathrm{V}$ while early maturing accessions were grouped in cluster III. Results of principal component analysis indicated that both yield and vegetative traits were the principal discriminatory characteristics. The accessions evaluated exhibited high diversity for most traits indicating that they can be used to develop varieties with desirable traits.
\end{abstract}

Keywords--- Variability, cluster and accessions

\section{INTRODUCTION}

Bambara groundnut (Vigna subterranea) is the third most important food legume crop after peanut and cowpea in Africa [1]. The crop is a good source of dietary protein especially for poor communities who cannot afford animal protein [2]. Based on its nutritional value, Bambara groundnut (BG) is considered to be a potential crop that can reduce on nutrition and food insecurity in Africa.

Despite its nutritional value, BG yields remain as low as 0.2 $\mathrm{t} \mathrm{ha}^{-1}$, largely because farmers still use traditional cultivars whose yield potential is low [3]. The continued use of low yielding BG cultivars has been attributed to lack of improved varieties. Presently, few studies have been undertaken to understand yield inheritance with its related traits in BG [4]. This limited understanding of yield inheritance has hindered breeding programs from developing high yielding BG varieties [5].

Apart from using low yielding BG cultivars, farmers continue to grow only local cultivars with preferred taste posing the non-preferred cultivars to extinct yet the nonpreferred cultivars may possess other good traits which can be utilized by breeders. Over generations, the practice of using preferred cultivars has led to considerable loss of BG genetic

National Crops Resource Research Institute, Kampala, Uganda

University for Development Studies, Tamale, Ghana

Maruku Agricultural Research Institute, Bukoba, Tanzania

University of Nigeria, Nsukka, Nigeria

Stellenbosch University, Cape Town, South Africa resources in Uganda; yet the national research institutes have not taken bold steps to conserve it.

The situation is further worsened by the fact that currently, there is no Consultative Group on International Agricultural Research Institution (CGIAR) operating in Uganda which is mandated to do research on

BG [6]. This has also made conserving and saving BG from extinct difficult. Hence, there is need to save the remaining BG genetic resources from extinction through collection and conservation.

Germplasm conservation alone is not enough to rescue BG from extinction but efforts to start a breeding program to support the development of improved BG varieties is critical. But, setting up of a breeding program for BG requires a clear understanding of its genetic variability in order to guide its improvement process as well as setting priorities for future germplasm collection expeditions. Bambara improvement can be achieved through breeding but the success in breeding depends on the choice of appropriate parental lines and how diverse the parental lines are [7]. The likelihood of attaining a wide range of variability in segregating generations can be increased by the inclusion of more diverse parents in hybridization program [8]. Therefore evaluating the levels and patterns of variability facilitates the investigation of genetic diversity in germplasm and further identifies diverse parental combinations that segregate with maximum genetic variability for appropriate selection [9] and introgression of desirable genes [10]. The information about genetic variability will simplify the selection of parental genotypes from random populations before attempting crosses and save time and resources [11] and also will help to make decision on management procedures of the BG germplasm.

A number of methods are now available to study crop variability, but morphological method is considered as the first step in description and classification of germplasm [12]. This method is direct, inexpensive and easy no wonder it is one of standard way of assessing genetic variation for many species, especially for under-researched crops such as BG [13]. This method has been used by [3] to characterize legume crops based on quantitative and qualitative traits. The same method also revealed substantial agro-morphological diversity and distinguished rice genotypes [15]. In addition, morphological characters which can be highly correlated to grain yield give breeders the choice to make decisions as to which traits to select for crops being evaluated [3]. Based on the success of morphological characters to determine the diversity in other crops, it was used to determine the genetic variability of BG accessions 


\section{MATERIALS AND METHODS}

Germplasm collection: Bambara groundnut germplasm was collected from four regions (Figure 1) of Uganda (South west, Central, Eastern and Northern) constituting 15 districts; Kabale and Kisoro (South west), Mbale, Sironko, Kamuli, Pallisa, Kumi and Soroti (Eastern) Lira, Dokolo, Apac, and Gulu (North) Bukomansibi, Lwengo, and Rakai (Central). The districts were selected based on their previous history of BG cultivation and their location within the agro-ecological zoning of Uganda. The germplasm was collected in form of seed from farmers and local markets which were $10 \mathrm{~km}$ apart. For each sample collected its identity information based on IPGRI descriptors [16] was recorded and the Global Positioning System (GPS) reading for that particular point was also recorded. The samples collected were placed in paper bags, labeled and transported to National Crops Resources Research Institute (NaCRRI), Namulonge for characterization.

Germplasm characterization: A field experiment was conducted at NaCRRI, Namulonge to characterize BG germplasm collected from Uganda. Namulonge lies at an altitude of 1150 m.a.s.l with bimodal rainfall pattern. It receives an average $1270 \mathrm{~mm}$ of rainfall annually with a mean temperature of $22^{0} \mathrm{C}$. The soils are red sandy clay loam type with a $\mathrm{pH}$ range of 4.9-5.0. Sixty nine accessions of BG were assembled for field evaluation during 2014B and 2015A rainy seasons. A randomized complete block design was used with three replications. Three BG seeds for each accession were planted in $2 \mathrm{~m}^{2}$ plot with inter-row and intra-row spacing of 50 $\times 20 \mathrm{~cm}$. Each plot was surrounded by two guard rows to safeguard the plants in darmacted plots from external interference. Three weeks later the seedlings were thinned to one seedling per hole. The fields were maintained weed free by hand hoeing three times at an interval of one weeding per month. Each weeding was accompanied with mounding of soil around each plant to create sufficient space for root and pod expansion.

Data collection: Ten weeks after planting, five plants per accession were randomly selected from each plot to record their quantitative data which included; terminal leaflet length $(\mathrm{mm})$, terminal leaflet width $(\mathrm{mm})$, petiole length $(\mathrm{mm})$, plant spread $(\mathrm{cm})$, plant height $(\mathrm{cm})$, internode length $(\mathrm{mm})$, peduncle length $(\mathrm{mm})$, number of flowers per peduncle, number of leaves, number of nodes per stem, number of branches per stem and number of stems per plant. Furthermore, traits related to growth duration such as days to $50 \%$ flowering and days to maturity were also recorded. Yield characters which were scored during and after harvest included, number of pods per plant, 100-seed weight (g), number of seeds per pod, and total yield were computed on a plot basis and extrapolated to yield per hectare. However, for qualitative data, five individual plants were recorded per plot to represent each BG accession and nine qualitative characters which were recorded included, testa colour, eye pattern, pod colour, pod texture, pod shape, seed shape, growth habit and stem hairness.

Statistical analysis: To test for variation among BG accessions for each trait, analysis of variance (ANOVA) was performed using Genstat version 14 [17]. The Mahalanobis's generalized distance $\left(\mathrm{D}^{2}\right)$ and principal component analysis were also done using Genstat statistical software, version 14. The clustering of the accessions was done following the Tocher's method [18].

\section{RESUlts AND DISCUSSION}

Observable characters: Twenty six characteristics were studied in sixty nine BG accessions. Based on the qualitative characteristics, most accessions had round shaped seeds (84\%) whereas minorities were oval shaped (16\%). Cream (75\%) and cream testa with grey butterfly-like eyes (53\%) were the most dominant seed and eye color respectively, (Table 1). But cream seeded accessions with grey double three lines on both sides of the eye $(30 \%)$ were also observed.

TABLE I

GROUPING OF VIGNA SUBTERREANEA ACCESSIONS BASED ON QUALITATIVE PARAMETER

\begin{tabular}{|c|c|}
\hline Trait & Category \\
\hline Growth habit & $\begin{array}{l}\text { A. bunch type }(0 \%) \text {, B. semi bunch } \\
\text { type }(19 \%) \text {, C. spreading type }(81 \%)\end{array}$ \\
\hline Terminal leaflet shape & $\begin{array}{l}\text { A. round }(0 \%), \text { B. oval }(100 \%), B \text {. } \\
\text { lanceolate }(0 \%)\end{array}$ \\
\hline Terminal leaf color & $\begin{array}{l}\text { A. green }(100 \%), \text { B. red }(0 \%), B \text {. } \\
\text { purple }(0 \%)\end{array}$ \\
\hline Stem hairness & $\begin{array}{l}\text { A. absent }(0 \%) \text {, B. sparse }(100 \%) \text {, } \\
\text { C. dense }(0 \%)\end{array}$ \\
\hline Pod color & $\begin{array}{l}\text { A. yellowish brown }(64 \%), \text { B. } \\
\text { brown }(16), \text { C. reddish brown }(20) \text {, } \\
\text { D. purple }(0 \%) \text {, E. black }(0 \%)\end{array}$ \\
\hline Pod texture & $\begin{array}{l}\text { A. smooth }(2 \%) \text {, B. little grooved } \\
(60 \%), \text { C. much grooved }(38 \%)\end{array}$ \\
\hline Seed shape & A. round $(84 \%)$, B. oval $(16 \%)$ \\
\hline Seed color & $\begin{array}{l}\text { A. cream }(75 \%), \text { B. grey }(15 \%), \text { C. } \\
\text { light red }(10 \%) \text {, }\end{array}$ \\
\hline Eye pattern & $\begin{array}{l}\text { A. cream test with black butterfly- } \\
\text { like eye }(17 \%) \text {, B. cream testa with } \\
\text { dark red butterfly-like eye }(30 \%) \text {, C. } \\
\text { cream testa with grey butterfly-like } \\
\text { eye }(53 \%)\end{array}$ \\
\hline
\end{tabular}

Cream color being dominant in the studied BG accessions indicated that most farmers select for cream color during planting. Although some farmers also plant a mixture of colors, but a survey done in Swaziland revealed that most farmers preferred BG landraces of cream color[19]; [20], which further confirms that in most African countries where $\mathrm{BG}$ is grown cream color is the most preferred. Bambara groundnut pod color ranged from brown to yellowish brown with little grooved pod texture $(60 \%)$ and much grooved pod (38\%). However, for pod shape, most BG accessions had round pods with pointed ending $(81 \%)$, while others were pointed with a nook (19\%). Besides, two growth habits; spreading type (81\%) and semi-bunch type (19\%) were observed indicating that farmers mostly select for the two growth habits. 
The two growth habits also reflected the type of cropping systems in which farmers use to cultivate BG. According to Odireleng [3], the spreading type accessions are useful in mixed cropping with other crops while the semi-bunch types are for monoculture [3]. On the other hand, the following qualitative characters; terminal leaf color, shape and stem hairness did not vary among BG accessions studied.

Due to significant variability observed among the BG accessions, it was necessary to classify the accessions based on the degree of divergence considering all the 17 traits. Based on diversity range, $69 \mathrm{BG}$ accessions were grouped into six clusters (Table 3). However, the clustering did not depend on the districts or agro-ecologies where BG was collected.

The distribution pattern among clusters revealed that the highest number of accessions where found in cluster I while the least number of accessions were in cluster VI (Table 3). Clusters II III IV and V comprised of 16, 5, 3 and 3 BG accessions, respectively.

The less number of accessions in clusters IV, V and VI was probably due to small number of traits and the duplication effect of traits included in the study. Earlier work by [15] in rice crop indicated that in hierarchical and dynamic clustering, the frequency of genotypes in a given cluster is increased by increasing the number of traits under study.

TABLE II

CLUSTERING OF BAMBARA GROUNDNUT ACCESSIONS BASED ON D ${ }^{2}$ STATISTICS

\begin{tabular}{|c|c|c|}
\hline $\begin{array}{l}\text { Cluster } \\
\text { Number }\end{array}$ & $\begin{array}{l}\text { Number of } \\
\text { accessions }\end{array}$ & Accessions \\
\hline $\mathrm{I}$ & 40 & $\begin{array}{l}\text { A3,A4,A5,A7,A8,A11,A13,A14, } \\
\text { A16,A19, A21,A22, } \\
\text { A23,A24,A25,A26,A28 A29, } \\
\text { A30, } \\
\text { A31,A32,A33,A34,A38,A41,A42 } \\
\text {,A44,A45,A47,A48,A50,A52, } \\
\text { A53,A56,A57,A59, A62, A64, } \\
\text { A67,A68 }\end{array}$ \\
\hline II & 16 & $\begin{array}{l}\text { A2,A10,A12,A17,A18,A27,A40, } \\
\text { A46,A49,A51,A54,A58,A60,A63 } \\
\text {,A65,A66 }\end{array}$ \\
\hline III & 5 & $\mathrm{~A} 1, \mathrm{~A} 37, \mathrm{~A} 39, \mathrm{~A} 61, \mathrm{~A} 69$ \\
\hline IV & 3 & $\mathrm{~A} 43, \mathrm{~A} 9, \mathrm{~A} 55$ \\
\hline $\mathrm{V}$ & 3 & A20,A6,A35 \\
\hline VI & 2 & A $15, \mathrm{~A} 36$ \\
\hline
\end{tabular}

$\mathrm{A} 1-\mathrm{A} 69=\mathrm{BG}$ accessions

Intra and inter-cluster divergence: Prior knowledge on the genetic variation based on agro-morphological characters is important in initiating any crop breeding work. The analysis of variance revealed that $\mathrm{BG}$ accessions differed significantly $(\mathrm{P}<0.05)$ for 17 quantitative traits studied (Table 2). This indicated the presence of variability among accessions, which signified that there is good opportunity for BG improvement if breeding work is initiated. These findings were in line with [3], who also reported significant differences in 23 characters among 24 characters that were studied to determine the genetic diversity and population structure of BG landraces in Swaziland. Similarly, [21] observed significant morphological variation for $13 \mathrm{BG}$ characters measured for two seasons in Tanzania.
The intra-cluster divergence was maximum in cluster II (8.09) and minimum in clusters V and VI (0.00), indicating that BG accessions in cluster II were more diverse than their counterparts in clusters V and VI (Table 4). The intra-cluster distances were only high for clusters I, II and IV and ranged from 1.49 to 8.09 , indicating the heterogeneous nature of $\mathrm{BG}$ accessions within each of the three clusters. The high intracluster divergence observed in cluster I, II and IV in the study were in line with findings by Forrester [1] who attributed the high divergence to seed exchange between farmers and the geographical proximate of the areas where the accessions are collected. On the other hand, the zero intra-cluster distance in clusters $\mathrm{V}$ and $\mathrm{VI}$, indicated that $\mathrm{BG}$ accessions in these clusters were homogenous.

In terms of inter-cluster distance, cluster VI showed maximum distance from cluster IV (24.93) followed by the distance between cluster IV and III (24.62), cluster I and IV (22.75), and cluster II and IV (21.42) ( Table 4) which reflected wide variability among these clusters. Minimum inter-cluster distance was found between BG accessions of the cluster II and VI (4.14) followed by the genetic distance between clusters III and VI (1.50) (Table 4). However, in some cases the inter-cluster distances where observed to be greater than the intra-cluster distance suggesting wide variability among accessions of the distant groups. Similar variability based inter and intra-cluster distances has been described in other crops rather than BG by various researchers [22]; [23].

TABLE III

ANALYSIS OF VARIANCE FOR 17 QUANTATIVE TRAITS OF 69 VIGNA SUBTERREANEA ACCESSIONS OBTAINED FROM UGANDA

\begin{tabular}{|c|c|c|c|}
\hline \multirow[t]{2}{*}{ Traits } & \multicolumn{3}{|c|}{ Source of variation ( Mean square) } \\
\hline & $\begin{array}{l}\text { Replication } \\
\quad(\text { d.f }=2)\end{array}$ & $\begin{array}{c}\text { Accessions } \\
(\text { d.f }=68)\end{array}$ & $\begin{array}{c}\text { Error } \\
(\mathrm{d} . \mathrm{f}=136 \\
)\end{array}$ \\
\hline Peduncle length & 6.8 & $354.8^{* * *}$ & 0.041 \\
\hline Number of leaves & 85.1 & $1258 * *$ & 1.11 \\
\hline $\begin{array}{l}\text { Terminal leaflet } \\
\text { length }\end{array}$ & 353.0 & $221.5^{* *}$ & 2.26 \\
\hline $\begin{array}{l}\text { Terminal leaflet } \\
\text { width }\end{array}$ & 50.2 & $65.9 *$ & 0.85 \\
\hline Petiole length & 156.8 & $1160.5^{* *}$ & 1.51 \\
\hline Plant spread & 20798 & $43836 * *$ & 17.36 \\
\hline Plant height & 137.6 & $3094.2 * *$ & 1.41 \\
\hline Internode length & 58.4 & $1096.8 * *$ & 0.92 \\
\hline $\begin{array}{l}\text { Number of nodes } \\
\text { per stem }\end{array}$ & 0.121 & $1.49 * *$ & 0.04 \\
\hline $\begin{array}{l}\text { Number of } \\
\text { branches per stem }\end{array}$ & 0.47 & $3.05 * *$ & 0.08 \\
\hline $\begin{array}{l}\text { Number of stems } \\
\text { per plant }\end{array}$ & 1.68 & $37.87 * *$ & 0.16 \\
\hline Pod/plant & 2717 & $265.2 * *$ & 6.27 \\
\hline Seed/pod & 0.1125 & $2.784 * *$ & 1.00 \\
\hline $\begin{array}{l}\text { Days to } 50 \% \\
\text { flowering }\end{array}$ & 4.69 & $7.49 * *$ & 0.26 \\
\hline Days to maturity & 4.49 & $37.67 * *$ & 0.25 \\
\hline 100 seed weight & 17.8 & $380.5 * *$ & 0.51 \\
\hline Yield $\left(\mathrm{Kgha}^{-1}\right)$ & 57401 & $2610374 * *$ & 28.8 \\
\hline
\end{tabular}

d.f $=$ degree of freedom, $* *$ significance at $5 \%$ level 
TABLE IV

INTRA AND INTER CLUSTER AVERAGE DISTANCES AMONG 69 BAMBARA GROUND NUT ACCESSIONS

\begin{tabular}{lllllll}
\hline $\begin{array}{l}\text { Cluster } \\
\text { Number }\end{array}$ & I & II & III & IV & V & VI \\
\hline I & $\mathbf{7 . 0 6 0}$ & 14.52 & 1.640 & 22.75 & 14.31 & 17.80 \\
II & & $\mathbf{8 . 0 7 0}$ & 3.300 & 21.42 & 5.800 & 4.140 \\
III & & & 1.490 & 24.62 & 9.020 & 1.500 \\
IV & & & & 7.620 & 15.62 & 24.93 \\
V & & & & & $\mathbf{0 . 0 0 0}$ & 9.480 \\
VI & & & & & & $\mathbf{0 . 0 0 0}$ \\
\hline
\end{tabular}

Values in bold illustrate the intra cluster distance and others show inter cluster distance

Cluster mean performance and their contribution towards divergence: The mean performance of different clusters for the traits evaluated indicated that the early maturing BG accessions were grouped into cluster III while cluster $\mathrm{V}$ included late maturing BG accessions indicating maximum contribution of growth durations towards the divergence between cluster III and V (Table 5).

Again all the high yielding accessions were grouped into cluster V whereas cluster II included low yielding accessions, implying maximum contribution of yield towards the divergence between cluster V and II. Cluster I was divergent from cluster IV mainly due to seed per pod, plant spread, number of nodes and stems per plant, indicating maximum contribution of these traits towards the divergence between the two clusters. On the other hand, cluster IV was divergent from cluster VI mainly due to yield and number of stems per plant. Based on these findings, the traits contributing maximally towards the divergence should be used as a basis for deciding which type of cluster would be considered for selection of best parents for hybridization [24].

The contribution of different traits towards the divergence was measured through principal component analysis (Table 6). The first principal component accounted for more than $21.8 \%$ of total variance, whereby number of flower peduncle, pod per plant, days to $50 \%$ flowering, days to maturity, 100 seed weight and yield were the variables that contributed most negatively (Table 6).

The first component identified mainly phenological variables presenting negative contributions. The second principal component accounted for more than $14.0 \%$ of total variance. Variables highly and negatively correlated were peduncle length, terminal leaflet length, plant height, number of nodes per plant and number of branches per plant, thus differentiating those accessions by vegetative characters which contribute to good architecture. Ntundu [21] observed similar patterns of loading in their study on 100 BG landraces in Tanzania, whereby the high loading within principal component one was mainly due to vegetative characters. The third principal component accounted for $11.5 \%$ of total variance and was associated with peduncle length, numbers of flowers per peduncle, number leaves, petiole length, plant height, number of branches, and stems per plant, hence differentiating those accessions by vegetative and flowering characteristics. This indicated the importance of these characters in identifying BG accessions that follow in the same cluster. These findings agree with Ntundu [21], who reported that vegetative characters were major factors contributing to the variation of $\mathrm{BG}$ germplasm.

TABLE V

CLUSTER MEAN OF DIFFERENT TRAITS AMONG 69 BAMBARA GROUNDNUT GERMPLASM

\begin{tabular}{|c|c|c|c|c|c|c|}
\hline \multirow[b]{2}{*}{ Traits } & \multicolumn{6}{|c|}{ Cluster numbers } \\
\hline & I & II & III & IV & $\mathbf{V}$ & VI \\
\hline $\begin{array}{l}\text { Peduncle } \\
\text { length }\end{array}$ & 37.2 & 35.1 & 39.6 & 39.2 & 39.5 & 45.7 \\
\hline $\begin{array}{l}\text { Number of } \\
\text { flowers per } \\
\text { peduncle }\end{array}$ & 1.4 & 1.3 & 1.2 & 1.4 & 1.3 & 1.4 \\
\hline $\begin{array}{l}\text { Number of } \\
\text { leaves }\end{array}$ & 60.9 & 45.9 & 45.6 & 76.6 & 54.0 & 57.0 \\
\hline $\begin{array}{l}\text { Terminal } \\
\text { leaflet length }\end{array}$ & 68.2 & 57.0 & 52.3 & 57.2 & 60.9 & 60.6 \\
\hline $\begin{array}{l}\text { Terminal } \\
\text { leaflet width }\end{array}$ & 33.0 & 23.5 & 22.0 & 28.0 & 24.3 & 24.7 \\
\hline Petiole length & 140.1 & 156.3 & 133.7 & 146.8 & 136.2 & 141.3 \\
\hline Plant spread & 428.1 & 323.7 & 341.7 & 328.1 & 335.4 & 348.4 \\
\hline Plant height & 187.1 & 213.4 & 170.5 & 185.3 & 180.8 & 176.6 \\
\hline $\begin{array}{l}\text { Internode } \\
\text { length }\end{array}$ & 22.3 & 18.7 & 14.4 & 19.7 & 16.0 & 17.5 \\
\hline $\begin{array}{l}\text { Number of } \\
\text { nodes per stem }\end{array}$ & 5.6 & 3.1 & 3.7 & 3.1 & 3.4 & 4.7 \\
\hline $\begin{array}{l}\text { Number of } \\
\text { branches per } \\
\text { stem }\end{array}$ & 2.0 & 2.4 & 1.9 & 2.9 & 3.2 & 3.9 \\
\hline $\begin{array}{l}\text { Number of } \\
\text { stems per plant }\end{array}$ & 8.4 & 7.6 & 7.7 & 14.3 & 10.4 & 8.7 \\
\hline Pod/plant & 30.1 & 25.0 & 29.9 & 32.3 & 40.5 & 31.8 \\
\hline Seed/pod & 1.8 & 1.4 & 1.7 & 1.4 & 1.5 & 1.6 \\
\hline $\begin{array}{l}\text { Days to } 50 \% \\
\text { flowering }\end{array}$ & 61.2 & 63.4 & 60.7 & 61.5 & 62.5 & 60.6 \\
\hline $\begin{array}{l}\text { Days to } \\
\text { maturity }\end{array}$ & 126.6 & 128.0 & 125.8 & 127.6 & 129.1 & 128.2 \\
\hline $\begin{array}{l}100 \text { seed } \\
\text { weight }\end{array}$ & 19.4 & 14.7 & 16.3 & 19.7 & 21.0 & 20.3 \\
\hline Yield $\left(\mathrm{Kgha}^{-1}\right)$ & 1648 & 1023 & 1968 & 1693 & 2922 & 2116 \\
\hline
\end{tabular}

\section{CONCLUSION}

The study exhibited that BG accessions from Uganda are genetically diverse and agro-morphometric characters can be employed to assess genetic variability and measure the extent of genetic relationship among the accessions. This study also revealed that Ugandan BG accessions constituted six major clusters. This clustering depends on yield, growth duration, vegetative and flowering traits. This was revealed by the PCA which exhibited the four major traits as the principal discriminatory traits among the clusters. The information generated on the degree of BG variability can be used for its improvement and also help to establish a core collection as part of the germplasm collection management.

\section{V.ACKNOWLEDGEMENT}

The research was supported by a grant from International Foundation of Science (IFS). The authors are grateful to National Crops Resources Research Institute for hosting the 
research and farmers for providing the BG accessions used in the study.

TABLE VI

PRINCIPAL COMPONENTS (PCS) FOR SEVENTEEN TRAITS IN BAMBARA ACCESSIONS

\begin{tabular}{lllc}
\hline & PC1 & PC2 & PC3 \\
\hline Eigen value & 8.95 & 3.28 & 1.12 \\
\% Variance & 21.8 & 14.0 & 11.6 \\
Cumulative (\%) total & 21.8 & 27.5 & 29.7 \\
variation & & & \\
Coefficient vector & & & \\
Peduncle length & 0.2429 & -0.1578 & -0.3130 \\
Number of flowers per & -0.0747 & 0.0378 & -0.1079 \\
peduncle & & & \\
Number of leaves & 0.1982 & 0.4231 & -0.2283 \\
Terminal leaflet length & 0.4143 & -0.0341 & 0.1576 \\
Terminal leaflet width & 0.3832 & 0.0667 & 0.1930 \\
Petiole length & 0.2805 & 0.0648 & -0.1453 \\
Plant spread & 0.4051 & 0.0544 & 0.0709 \\
Plant height & 0.3160 & -0.0176 & -0.2019 \\
Internode length & 0.2029 & 0.1645 & 0.3849 \\
Number of nodes per stem & 0.3669 & -0.2736 & 0.1287 \\
Number of branches per stem & 0.1959 & -0.0105 & -0.1045 \\
Number of stems per plant & 0.0439 & 0.5152 & -0.2455 \\
Pod/plant & -0.0239 & 0.1565 & 0.3027 \\
Seed/pod & 0.0459 & -0.3013 & 0.3564 \\
Days to 50\% flowering & -0.0090 & 0.4143 & 0.1192 \\
Days to maturity & -0.0201 & 0.3371 & 0.3302 \\
100 seed weight & -0.0239 & 0.1565 & 0.3027 \\
Yield (Kgha ${ }^{-1}$ ) & -0.1253 & 0.1166 & 0.3633 \\
\% variation explained & 21.8 & 14.0 & 11.6 \\
\hline
\end{tabular}

\section{REFERENCES}

[1] Forrester,O., Odongo, Oyoo, M.E, Wasike V, J.O Owuoche, L Karanja and Korir P. (2015). Genetic diversity of Bambara groundnut (Vigna Subterranea $L$. verdc) landraces in Kenya using microsatellite markers, African Journal of Biotechnology, 14:283-291 https://doi.org/10.5897/AJB2014.14082

[2] Physical properties of bambara groundnuts. J. Food Eng., 47, 321-326. https://doi.org/10.1016/S0260-8774(00)00136-9

[3] Odireleng, OM, 2012: Genetic Diversity and Population structure analysis of Bambara groundnut [Vigna subterranea (L.) Verdc.] Landraces using Morpho-agronomic Characters and SSR Markers $\mathrm{PhD}$ Thesis, University of Nottingham

[4] Basu S., Mayes S., Davey M., Roberts J.A., Azam-ali S.N., Mithen R. and Pasquet R.S. (2007). Inheritance of 'domestication' traits in Bambara groundnut (Vigna subterranea (L.) Verdc.) Euphytica 157: 59-68

https://doi.org/10.1007/s10681-007-9396-4

[5] Oyiga B.C., Uguru M.I. and Aruah C.B. (2010), Studies on the floral traits and their implications on pod and seed yield in Bambara groundnut (Vigna subterranea (L.) Verdc.), Australian Journal of Crop Science 4: 91- 97

[6] Mayes S., Basu, S., Murchie E., Roberts J.A., Azam-ali S.N., Stadler F., Mohler V., Wenzel G., Massawe F., Kilian A., Bonin A., Beena A. and Sheshshayee M.S.(2009), BAMLINK - a Cross disciplinary programme to enhance the role of bambara groundnut (Vigna subterranea L. Verdc.) for food security in Africa and India. Acta Horticulturae 806: 137 - 150.

https://doi.org/10.17660/ActaHortic.2009.806.15

[7] CIMMYT 1997. The genetics and exploitation of heterosis in crops: An International Symposium, 17-22 August 1997, Mexico City, Mexico: Book of Abstracts. CIMMYT; 1997.

[8] Joshi AB, Dhawan NL 1996. Genetic improvement in yield with special reference to self- fertilizing crops. Indian J. Genet. 26:101-13
[9] Barrett B, Kidwell K, Fox P. (1998).Comparison of AFLP and pedigree-based genetic diversity assessment methods using wheat cultivars from the Pacific Northwest. Crop Science. 38:1271-1278. https://doi.org/10.2135/cropsci1998.0011183X003800050026x

[10] Thompson JA, Nelson RL, Vodkin LO. (1998). Identification of diverse soybean germplasm using RAPD markers. Crop Science. 38:1348-1355 https://doi.org/10.2135/cropsci1998.0011183X003800050033x

[11] Hallauer A.R, Miranda J. (1988). Quantitative genetics in maize breeding.2nd ed. Iowa State Univ Press, Ames, IA. 28:869

[12] Hedrick P.W. (2005), Genetics of populations, Jones and Bartlett, London, UK.

[13] Azam-ali S.N., Sesay A., Karikari S.K., Massawe F.J., AguilarManjarrez J., Bannayan M, and Hampson K.J. (2001). Assessing the potential of an underutilized crop- a case study using bambara groundnut, Experimental Agriculture 37: 433 - 472 https://doi.org/10.1017/S0014479701000412

[15] Ahasanul, H., S. N. Begum, A. H. K. Robin and Lutful H., 2015. Partitioning of Rice (Oryza sativa L.) Genotypes Based on Morphometric Diversity American Journal of Experimental Agriculture 7: (4) ISSN: 2231-0606

[16] IPGRI, IITA, BAMNET (2000). Descriptors for bambara groundnut (Vigna subterranea), International Plant Genetic Resources Institute, Rome, Italy; International Institute of Tropical Agriculture, Ibadan, Nigeria; International Bambara Groundnut Network, Germany.

[17] Payne RW, Murray DA, Harding SA, Baird DB, Soutar DM. Gen Stat for windows $\left(14^{\text {th }}\right.$ eds $)$ introduction. VSN International, Hemel; 2014.

[18] Rao CR. 1952. Advanced statistical methods in biometric research. John Wiley \& Sons, New York;

[19] Oyiga B.C., Uguru M.I. and Aruah C.B. 2010. Studies on the floral traits and their implications on pod and seed yield in Bambara groundnut (Vigna subterranea (L.) Verdc.), Australian Journal of Crop Science 4: 91 - 97

[20] Brink M, Belay G. 2006. Ressources ve'ge'tales de l'Afrique tropicale 1: Ce'réales et le'gumes secs [Traduction de: Plant resources of tropical Africa 1. Cereal and pulses].Leiden: Backhuys Publishers (in French).

[21] Ntundu W.H., Shillah S.A., Marandu W.Y.F. and Christiansen J.I. (2006), Morphological diversity of bambra groundnut [Vigna subterranea (L.) Verdc.] Landraces in Tanzania, Genetic Resources and Crop Evolution 53: 367 - 378 https://doi.org/10.1007/s10722-004-0580-2

[22] Panigrahi KK, Sarka KK, Baisakh B, Mohanty A.(2014) Assessment of genetic divergence in potato (Solanum Tuberosum L.) genotypes for yield and yield attributing traits. International Journal of Agriculture, Environment and Biotechnology. 7:247-254. https://doi.org/10.5958/2230-732X.2014.00241.1

[23] Zia-ul-Qamar, Akhtar J, Ashraf M, Akram M, Hameed A. 2012. A multivariate analysis of rice genetic resources. Pak J. Bot. 44:13351340.

[24] Latif M, Rahman M, Kabir M, Ali M, Islam M, Rafii M. (2011).Genetic diversity analyzed by quantitative traits among rice (Oryza sativa L.) genotypes resistant to blast disease. Afr J Microbiol Res. 2011; 5(25):4383-4391 https://doi.org/10.5897/AJMR11.492 